\title{
Carcinoma Ex Pleomorphic Adenoma in a Minor Salivary Gland of the Hard Palate: Report of a Case
}

\section{Sert Damağın Minör Tükrük Bezinde Karsinoma Ex Pleomorfik Adenom: Bir Olgu Sunumu}

\author{
Ferhat Bozkus ${ }^{1, *}$, Sezen Kocarslan ${ }^{2}$, Ismail Iynen $^{1}$, Rıza Dundar ${ }^{1}$ \\ ${ }^{1}$ Department of Otolaryngology - Head and Neck Surgery, Harran University, Sanliurfa, Turkey \\ ${ }^{2}$ Department of Pathology, Harran University Hospital, Sanliurfa, Turkey
}

\begin{abstract}
Carcinoma ex pleomorphic adenoma (CEPA) is defined as a epithelial malignancy arising from pleomorphic adenoma. CEPA is an agressive malignancy that commonly develops in a primary or recurrent PA. CEPA is an uncommon neoplasm of the minor salivary gland. The palate is the most common region for minor salivary gland tumours. Less than $7 \%$ of the cases occur in the palatal minor salivary glands. In this report we present a case of CEPA in a hard palate minor salivary gland of a 74 years old female patient.
\end{abstract}

Key Words: Carcinoma, pleomorphic adenoma, hard palate

\section{Introduction}

Minor salivary gland neoplasms have a high rate of developing malignancy. Pleomorphic adenoma $(\mathrm{PA})$ is the most common minor salivary gland neoplasms. This is followed by mucoepidermoid carcinoma (1). Carcinoma ex pleomorphic adenoma (CEPA) is defined as a epithelial malignancy arising from pleomorphic adenoma (2). CEPA is an agressive malignancy that commonly develops in a primary or recurrent PA (3). CEPA is an uncommon neoplasm of the minor salivary gland (1-4). The palate is the most common region for minor salivary gland tumours $(1,5)$. Less than $7 \%$ of the cases occur in the palatal minor salivary glands $(3,5)$.

CEPA constitute about $3.6 \%$ of all salivary gland tumors and $12 \%$ of all salivary gland malignancies $(2,3)$. Most CEPAs occur in the parotid gland $(2-$ 4,6). The risk of malignant transformation can appear highly in either long-standing or recurrent

\section{ÖZET}

Karsinoma ex pleomorfik adenom (CEPA) pleomorfik adenomdan kaynaklanan epitelyal malignensi olarak tarif edilir. CEPA primer ya da rekürren pleomorfik adenomdan gelişen agresif bir malignensidir. CEPA minör tükrük bezinin nadir görülen bir tümörüdür. Minör tükrük bezi tümörlerinin en yaygın görüldüğü bölge damaktır. Vakaların \% 7'den daha azı palatal minör tükrük bezlerinde oluşur. Biz bu yayında 74 yaşında bir kadın hastada sert damak minör tükrük bezinden gelişen bir CEPA vakasinı sunmaktayı.

Anahtar Kelimeler: Karsinom, pleomorfik adenom, sert damak

pleomorphic adenomas $(1,3,5,7)$. It is extremely rare in young patients. It grows up about 13 years later than PA $(1,8)$. We present a case of CEPA in a hard palate minor salivary gland of a 74 years old female patient.

\section{Case Report}

74-year-old female patient presented with an painless lump has been 30 years in the midline of the hard palate. The lump had slowly increased in size for the last 6 mounths. There were no systemic symptoms or medical history of note. Clinical examination showed a $4 * 4$ tumour arising from the midline of the hard palate. The mass was exophytic,ulcere, nodular with overlying mucosa of normal appearance (Figure 1). Palpation of submandibular and cervical lymph nodes were negative. The findings of the rest of the head and neck examination were not remarkable. Magnetic resonance imaging scans showed a large mass on 
the hard palate extending inferiorly soft palate (Figure 2). An excisional biopsy was performed under general anesthesia which revealed a mass that appeared to be irregular surface (Figure 3).

The material was observed to be $5 \times 4 \times 3 \mathrm{~cm}$ dimensions and to be an irregular surface by macroscopic examination. The surface of the lesion with irregular margins that was $3 \mathrm{~cm}$ in diameter was detected on cross-sectional area of the material. Histopathological examination of the lesion demonstrated that well-differentiated mucoepidermoid carcinoma in large areas but features of the pleomorphic adenoma in focal areas.

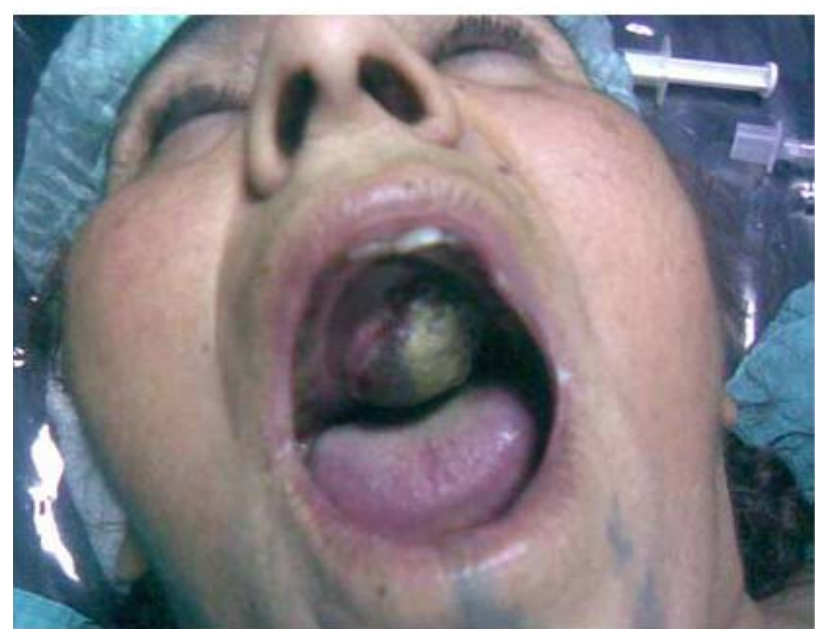

Fig. 1. $4 \mathrm{~cm}$ sized flat,ovoid,ulcerated lump in midline site of hard palate.

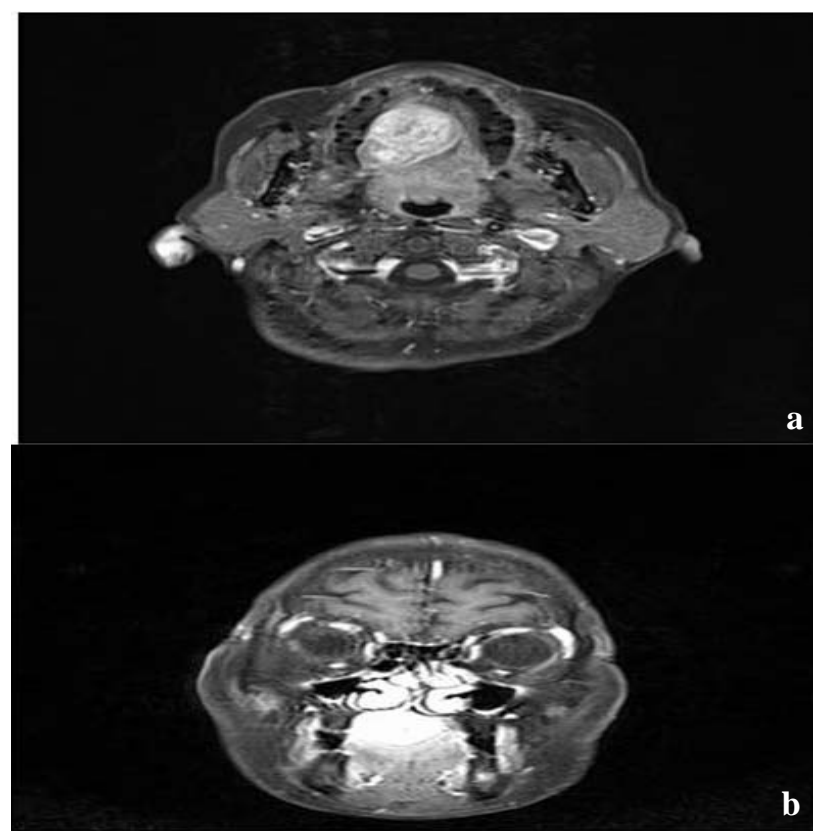

Fig. 2. Magnetic resonance imaging scans showed a large mass on the hard palate extending inferiorly soft palate a; Axial imaging scans. b; Coronal imaging scans.

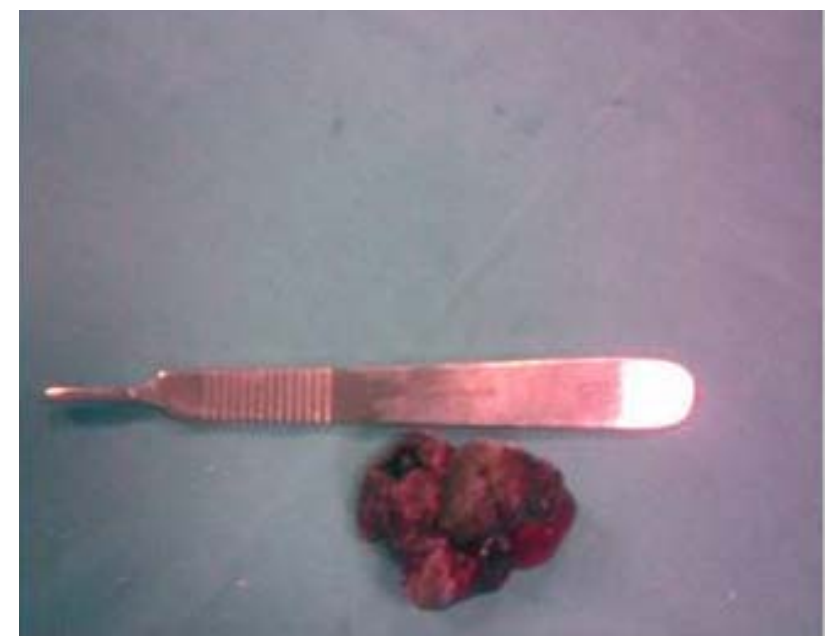

Fig. 3. Excised mass was appeared to be an irregular surface.

Foci of necrosis and hemorrhage were found in areas of carcinoma. Four types of cells were determined including epidermoid, intermediate, clear and mucous cells. Prominent mitosis and pleomorphism were not detected in these cells. Positive staining with musicarmine was observed on mucous cells by histochemical staining. Epithelial and mesenchymal foci were seen in pleomorphic adenoma areas. The epitelial cells composed of cells that have oval spindle nucleus and necrosis haven't been seen. These cells were composed of solid areas and tubular structures. Some areas were detected to be mixoid on floor. Mesenchymal component was contained in the cartilaginous areas (Figure $4 \mathrm{a}-\mathrm{f}$ ). Surgical margins were negative.

Neck dissection was not performed because of Neck MRI demonstrated nonpathological lymphadenopathy, Patient was evaluated by a radiation oncologist. It was decided not to apply radioteraphy to the patient. At 12 mounths' follow up the patient has been well.

\section{Discussion}

Pleomorphic adenoma is the neoplasm that's most commonly seen in the minor salivary glands. The incidence ranges from 33\% to 70 (7). Malignant differentiations of pleomorphic adenomas of salivary gland origin are uncommon and include three varied subtypes.

Carcinoma ex pleomorphic adenoma is the most commonly seen malignant change and constitute about $12 \%$ of all salivary gland malignancies $(2,3)$. The other subtypes are Carcinosarcoma and metastasizing pleomorphic adenoma. Less than $7 \%$ of the cases occur in the palatal minor salivary 

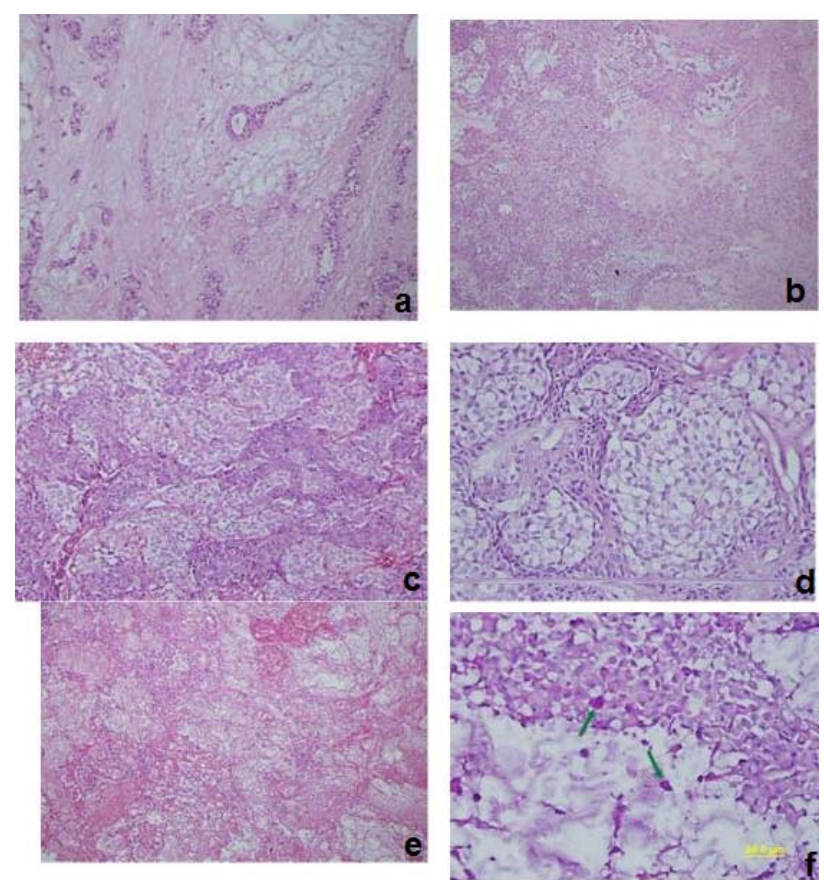

Fig. 4. The photomicrography of well- differentiated mucoepidermoid carcinoma arising from the ground of pleomorphic adenoma. a; Epiteloid component in small islans on the mixoid ground (H\&E, x200). b; The cellular epiteloid areas and cartilaginous mesenchymal component properties in another area of pleomorphic adenoma (H\&E, x200). c; The areas of the tumour that is composed of epidermoid and intermediate cells on the focus of welldifferentiated mucoepidermoid carcinoma (H\&E, x200). d; The clear cells in another area of carcinoma (H\&E, $\mathrm{x} 400)$. e; Extensive tumour necrosis on carcinoma (H\&E, x200). f; Intracytoplasmic (arrows) positive for mucin with mucicarmine demonstrated in mucous cells. (mucicarmine $\mathrm{x} 400$ )

glands $(3,5)$. These tumors are characterized by high rates of recurrence, metastasis (3). The palate is the most frequent region for minor salivary gland tumours $(1,5)$. The mechanism of malignant changes of pleomorphic adenomas has been argued by many of authors. Malignancy may occur in long-standing and recurrent pleomorphic adenomas $(1,5)$.

The clinical characteristics of CEPA may be parallel to PAs and the most commonly symptom was an asymptomatic mass and occasionally there is a ongoing history for a long time of PA (3). CEPA is rare in the minor salivary glands and accounts for less than $7 \%$ of all cases $(3,5)$. Oftenly patients report that a painless mass has been present for a long time.

Occasionally rapidly growth may be seen which initially caused the pain and ulceration. Our patient presented with an mucoepidermoid carcinoma (MEC) in pre- existing pleomorphic adenoma and had a prolonged history and recently rapid growth in palatal lump. CEPA usually occurs in the 6 th $\sim 8$ th decades of life (3). Our patient was also 74 years old. The imaging findings of CEPA are usually nonspecific and was difficult to distinguish from those of other benign and malignant salivary gland tumors. PA shows a variety of signal insensities due to the cytomorphologic and architectural variabilites and is hard to be differantiated from lowe- grade malignant tumors in the absence of an irregular margin or infiltration into the surrounding tissue (6). Our patient were demonstrated the imaging findings of benign tumor. A wide surgical excision with adequate margins is essential for a favorable outcome in patients with malignant minor salivary gland tumors $(1,5)$. Patients with positive margins are more likely to have locoregional recurrence than those with negative margins (7). Postoperative radiotherapy is reserved for patients with highgrade tumor histology, large primary lesions, perineural invasion, bone invasion, cervical lymph node metastasis, and positive margins (1).

Postoperative radiotherapy were not applied to our patient due to manifested negative margins, negative cervical lymph node metastasis and intermediate tumor histology and negative bone invasion. Carcinomas ex pleomorphic adenoma generally display aggressive behavior. They have high recurrence and metastatic rates, which vary from $25 \%$ to $75 \%$ (1). Recurrence, especially regional and distant metastasis leads to extremely poor prognosis $(1,5)$.

This case demonstrates that unexpected malignancy may occur in what primarily is considered to be a pronounced benign tumor of minor salivary gland tissue, and Careful histopathological evaluation can only help to us in the detection of such extremely rare salivary gland tumors including carcinoma ex pleomorphic adenoma.; Early and adequate removal of malignant mixed tumors of the ,minor salivary glands is extremely critical. Because of when recurrence and distant metastasis occur, survival is remarkably low.

\section{References}

1. Mcnamara ZJ, Batstone M, Camile S. Carcinoma ex pleomorphic adenoma in a minor salivary gland of the upper lip. Oral Surg Oral Med Oral Pathol Oral Radiol Endod 2009; 108(5): 51-53. 
2. Reichart PA, Kalz S, Rabel A, Bornstein MM. Carcinoma ex pleomorphic adenoma in a minor salivary gland: report of a case. Oral Maxillofacial Surg 2010; 14(1): 59-62.

3. Chen HH, Lee LY, Chin SC. Carcinoma ex pleomorphic adenoma of soft palate with cavernous sinus invasion. World Journal of Surgical Oncology 2010; 8: 24.

4. Akan H, Yildiz L, Unal R. Carcinoma ex pleomorphic adenoma in a minor salivary gland with pulmoner metastasis. Diagn İnterv. Radiol 2008; 14(1): 3-5.

5. Furukawa M, Suzuki H, Matsuura K, Takahashi E, Suzuki H, Tezuka F. Carcinoma ex pleomorphic adenoma of the palatal minor salivary gland with extension into the nasopharnx. Auris Nasus Larynx 2001; 28(3): 279-281.

6. Kato H, Kanematsu M, Mizuta K, Ito Y, Hirose Y. Carcinoma ex pleomorphic adenoma of the Parotid Gland: Radiologic- Pathologic Correlation with MR Imaging Including Diffusion-Weighted Imaging. Am. J. Neuroradiol 2008; 29(5): 865-867.

7. Benazzou S, Boulaadas M, Sefiani S, El Kohen A, Essakalli L, Kzadri M. Mucoepidermoid Carcinoma Arising From Pleomorphic Adenoma of the Soft Palate. The journal of Craniofacial Surgery 2006; 17(6): 1192-1194.

8. Negahban S, Daneshbod Y, Shishegar M. Clear cell carcinoma arising from pleomorphic adenoma of a minor salivary gland. Acta Cytol 2006; 50(6): 687-690. 